\title{
Creating a climate for expanded trade for Canadian wood products - Government of Canada ${ }^{1}$
}

\author{
by Jean McCloskey ${ }^{2}$
}

\section{Introduction}

I am pleased to bring the federal perspective to this discussion about creating a climate for expanded trade for Canadian wood products. This is an area where the Government of Canada has a strong role to play in supporting Canadian exports and exporters. The federal government, in cooperation with the provinces, works to promote sustainable forest management which will, in turn, help ensure a long-term wood supply for industry.

\section{Importance of Forestry to Canada}

Directly and indirectly, the forest provides jobs for one in every 15 Canadians, many of whom are located in some 350 rural communities from coast to coast. The importance of forestry to job creation and exports cannot be overstated. In 1995, more than

Une part importante des activités du gouvernement du Canada et du ministère des Ressources naturelles vise à faire valoir les intérêts des exportateurs canadiens à l'étranger. Avec des exportations évaluées à plus de 21 milliards de dollars l'an dernier, le secteur des produits du bois est un géant commercial au Canada. Travaillant de concert avec d'autres ministères fédéraux, les intervenants du secteur et nos partenaires commerciaux, le Ministère intervient dans les dossiers de l'heure touchant le commerce extérieur. Il s'efforce de vois à ce que les marchés d'exportation demeurent ouverts aux produits du bois et que de nouveaux marchés soient développés.

Par exemple, nous collaborons avec les provinces et le secteur privé afin de projeter dans le monde une image dynamique, sur le modèle d'Équipe Canada. Nous concentrons nos efforts sur les petites et moyennes entreprises qui exercent des activités sur le marché international, car ces dernières génèrent le plus grand nombre de nouveaux emplois au pays. À cette fin, le Service canadien des forêts travaille avec Forintek, avec des organismes nationaux comme le Conseil canadien du bois et avec des partenaires commerciaux à l'échelle internationale pour établir des normes de produit et assurer une plus grande transparence dans ce domaine.

D'autre part, nous participons activement à diverses initiatives bilatérales et multilatérales en vue de la libéralisation et de la facilitation du commerce international. Le Canada siège au sein de l'Organisation mondiale du commerce et joue un rôle de premier plan dans l'Organisation de coopération économique AsiePacifique, puisque cette région sera le principal moteur de la croissance économique mondiale au cours du prochain siècle. Nous nous assurons ainsi que le commerce s'effectue selon les règles convenues par la communauté internationale et en l'absence de toute restriction arbitraire.

Nous jouons également un rôle actif dans le dialogue sur les forêts qui se tient sur la scène internationale par la Commission des Nations Unies pour le développement durable et par l'Organisation des Nations Unies pour l'alimentation et l'agriculture. Enfin, nous apportons une large contribution aux travaux visant à établir une convention mondiale sur les forêts.

${ }^{1}$ Paper presented at the semi-annual meeting of the Canadian Wood Council, 21 October 1996.

${ }^{2}$ Deputy Minister, Natural Resources Canada, Ottawa.
\$21 billion dollars worth of wood products was exported and after the first seven months of 1996 , exports stand at $\$ 9.1$ billion. The forest industry is certainly a powerhouse in terms of Canadian trade.

While most of our wood products are exported to the US, Japan is our largest offshore market. Last year, Japan purchased $24 \%$ of Canada's lum-

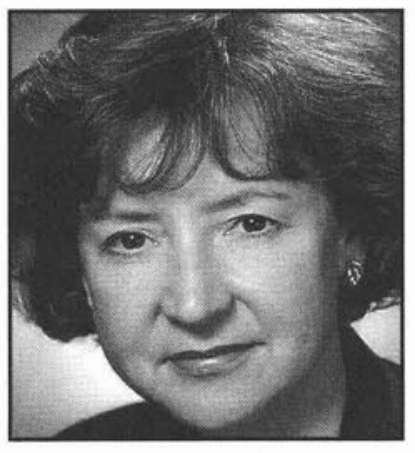
ber exports. In recent years, the European Union has declined in terms of its importance as an export destination, due, in large part, to our trade dispute with the European Union over the pinewood nematode.

The solid wood sector contributes to all areas of Canada's employment and comprises many small and medium sizes enterprises - or SMEs. The Government of Canada has focused on this sector of the economy because that is where the largest number of jobs are currently created. SMEs offer significant potential to contribute to the government's jobs and growth objectives.

To ensure this potential, the Government of Canada is committed to working with industry and our trading partners to open doors on new market opportunities, and to maintain Canada's share of existing markets for forest products.

For the purposes of this discussion, then, the management, development and implementation of international trade initiatives can be broken down into two major categories, namely "international business development" - or trade promotion and expansion - and "market retention" - or trade policy and market access.

\section{International Business Development}

The Department of Foreign Affairs and International Trade and Industry Canada lead the development of the Canadian International Business Strategy - or CIBS. Developed under a "Team Canada" approach, the strategy is designed to focus government and industry efforts in each sector of the economy. Essentially, the goal is one-stop-shopping for Canadian exporters.

There are two major components of the CIBS. The first establishes National Sector Teams to develop trade strategies. The second component is a domestic support program to help new exporters and SMEs enter the exciting but challenging world of international marketing.

The domestic support program recognizes that while Canada is export dependent, too few companies are exporting. Some ten percent of Canadian companies are responsible for 90 percent of the exports.

Two national sector teams of relevance to Canadian Wood Council clientele are the Forest Products Sector Team and the Building Products Team. The objectives of each team include developing and implementing a strategy, with input from 
overseas posts, the private sector, provinces and support from organizations such as the forest industry.

The first versions of strategies for each sector are in draft form. Although these drafts need refining, the documents and supporting materials, which include lists of currently planned promotional events, are available both in hard copy and electronically. Work is also underway to develop a companion strategy to retain and expand foreign investment into Canada - and the forest sector has been identified as a priority in this particular initiative.

\section{Trade Policy and Market Access}

The topic of trade policy and market access comprises two major categories: trade liberalization - tariff levels, for example - and trade flow impediments, or non-tariff barriers.

\section{Trade Liberalization}

Canada depends on exports. We are a major trading country, but at the same time, Canada is a modest economic power in the global economy. As a result, for Canada, free trade and market access using a trading system based on clear rules is necessary for our continued prosperity and growth. This is why we continue to play an active role in so many trade liberalizing initiatives.

For example, Canada worked hard to improve not only the tariff structure but the rules based regime in the latest Uruguay Round of GATT negotiations, including the establishment of the World Trading Organization. While we did not get everything we wanted in the round, we saw some progress toward global free trade in forest products. The trade rules regarding the technical barriers to trade and the phytosanitary clauses were tightened. Discussions to improve the agreement we reached are continuing. In addition, when Chile's accession to NAFTA stalled, due to the expiration of US negotiating authority, Canada began negotiations with Chile to establish a bilateral free trade agreement as an interim measure.

We recently concluded a free trade agreement with Israel and preliminary discussions are underway with New Zealand as well.

Canada is an active player in the Asia Pacific Economic Cooperation on process to reach a free trade agreement among the Asia Pacific countries - including important markets like Japan and Australia. This work will take on increased importance for Canada next year, because 1997 has been designated "Canada's Year of Asia Pacific." Therefore, Canada will hold the chair.

Canada also continues to play a lead role in establishing a free trade arrangement between North and South American countries - also known as the Free Trade of the Americas process.

These are longer term projects, but they are all aimed at liberalizing trade within a rules-based trading regime. Each successive round of GATT negotiations has resulted in reducing tariffs.

\section{Trade Flow Impediments}

However, as tariffs have come down, we have seen other countries increase the use of non-tariff barriers to protect domestic industries. These trade flow impediments include product standards, building codes, plant health rules, environment standards and the introduction of eco-labelling.

At the department of Natural Resources, the Canadian Forest Service works with domestic organizations such as the CWC, Forintek and our international trading partners to ensure that product standards setting and management are open and transparent.

The goal of this partnership is to ensure that Canadian forest products are not discriminated against unfairly. In addition, where it is feasible, we pursue mutual recognition agreements, whereby trading partners will accept Canadian products into their market and consider them as meeting local standards, if they meet a comparable Canadian or international standard such as ISO.

We are also working with officials in key markets to influence the establishment of building codes and standards that correspond with Canada's timber frame system for residential construction. This opens the door for products like lumber and plywood, and for many value-added building products, up to, and including, pre-engineered homes.

For example, the Japanese Ministry of Construction now recognizes the National Lumber Grades Authority (NLGA) standard for Canadian lumber for use in Japan's two-by-four housing construction industry. This demonstrates how government and industry can work together to develop international acceptance of Canadian standards.

The Canadian government has recently signed a softwood lumber agreement with the United States. At the forest industry's request, we negotiated a deal with the US that gives Canadian softwood lumber exporters a guarantee against US trade actions for the next five years.

The bottom line on trade is flexibility and pragmatism. In fact, this situation emphasizes the need for market diversification and new product development - key aspects of our discussion here today.

The federal department of Natural Resources participates directly in a number of partnerships with industry and with research institutes to address various non-tariff barriers. For example, Forintek Canada Corp. conducts research under contract with the Canadian Forest Service of the Department to investigate the performance of timber structures under seismic and wind loads. This is crucial in Japan and the research also influences the work to develop codes and standards designed to enhance our market access.

\section{International Dialogue}

In today's world, trade liberalization and market access also depend on the reputation of the supplying country in terms of resource management. As the custodian of ten per cent of the world's forests, and as the world's largest exporter of forest products, Canada is very much in the public eye around the world.

Hence, to complement our trade endeavours, we play an active role in the international forestry dialogue through participation in organizations such as the United Nations Commission for Sustainable Development and the Food and Agriculture Organization - or FAO. Canada's goal is to reach a consensus and develop an International Forestry Convention.

To support our international positions and develop a network of living forest laboratories, Canada developed the concept of the Model Forest which led to the establishment of 10 - soon to be 11 - model forests across Canada. This newest addition will be an aboriginal-led model forest.

The concepts proved to be of such value that the program has received international acclaim and countries from around the world have either joined the network or have expressed an interest in joining the process.

Today, global markets place a greater emphasis on sustainable 
forest management as a condition for market acceptance. The industry-led Canadian Standards Association certification process was initiated to address this development. The certification has been designed to address all forest values from timber to non-timber goods and services.

The Canadian Forest Service has also responded to the challenge. CFS is focusing its research on broad forest management issues in order to give forest stakeholders the tools to perfect sustainable forest management. Directly or indirectly, their research efforts contribute to global market access, wealth and job creation, and environmental protection.

\section{Conclusion}

The Government of Canada is committed to a wide range of activities to support and improve Canada's trade in forest products. Federal officials are working together and with the provinces and the private sector to fine-tune a national strategy through the Canadian International Business Strategy that focuses on the "Team Canada" approach.
We are concentrating on support to small and medium sized enterprises to assist companies develop their expertise in the highly complex area of international trade. The goal is to increase the number of Canadian companies exporting their products.

At the same time, we continue to work hard, bilaterally and multi-laterally, to improve tariff structures and strengthen trade rules through the World Trade Organization, through APEC, and in the development of the FTAA, which could lead to the creation of a free-trade area in North and South America.

In addition, the Department of Natural Resources has a strong role to play in cooperation with Canadian research organizations, and institutes in other countries to promote acceptance of Canadian standards for wood products. This work is key to meeting the challenge of non-tariff barriers to international trade. However, we cannot meet the complex challenges of international trade on our own. We need the continued support of the private sector and the partners like the CWC. 